\title{
Wilson Disease and Its Current Problems
}

\author{
Masaru Harada
}

Key words: compliance, suicide, Wilson disease

(Inter Med 49: 807-808, 2010)

(DOI: 10.2169/internalmedicine.49.3380)

Wilson disease is an autosomal recessive disorder characterized by the progressive accumulation of copper in the body. The failure of hepatocytes to excrete copper into bile and the decreased copper incorporation into ceruloplasmin causes the metal to accumulate in the body (1-5). In 1993, Wilson disease gene, $A T P 7 B$, was identified by separate groups (6-8). $A T P 7 B$ encodes a metal-transporting P-type adenosine triphosphatase (ATPase), which is expressed mainly in hepatocytes and functions in the excretion of copper into bile probably via the late endosome and lysosome $(2,5)$. Failure of this system results in copper accumulation in the body. Previously we did not have effective treatment for this progressively fatal disorder. However, now there are several treatments for this disorder. The clinical outcome of patients with Wilson disease has improved owing to the introduction of various drugs that reduce the copper accumulation in the body after the first description of Dpenicillamine by Walshe (9). Therefore, Wilson disease is now one of the rare inherited disorders for which effective pharmacologic treatment is available $(3,4)$. There are several available therapies for Wilson disease, such as Dpenicillamine, trientine, zinc salts and tetrathiomolybdate. Liver transplantation is an option for severe patients with Wilson disease and is curative (4). Furthermore, living-donor liver transplantation is also safe even using grafts from het- erozygous donors (10).

However, there are still some problems regarding the management of patients with Wilson disease as suggested by Tatsumi et al (11) in this issue of Internal Medicine. The serious problems include non-compliance of the therapy and attempted suicide. Discontinuance of the treatment for Wilson disease often induces intractable hepatic failure even in previously stable patients (12-15). Although the mechanism has not been clearly demonstrated, restart with full dose of D-penicillamine may be associated with paradoxical worsening of symptoms (14). Most patients with this condition need liver transplantation (4). Because many patients are diagnosed at a young age, we should carefully educate these patients about this problem. Another problem is suicide as described Tatsumi et al (11). Suicide may be one of the psychiatric problems due to depression, decreased functional capacity, hopelessness or the need of long-term treatment (16). One report stated attempted suicide in as high as 7 of 45 patients with Wilson disease (17). In the management of patients with Wilson disease careful attention to prevent attempted suicide is important.

We should be aware of these problems and carefully educate patients with Wilson disease, because Wilson disease is one of the first fatal genetic diseases for which we now have several useful treatment strategies.

\section{References}

1. Terada K, Nakako T, Yang XL, et al. Restoration of holoceruloplasmin synthesis in LEC rat after infusion of recombinant adeno virus bearing WND cDNA. J Biol Chem 273: 1815-1820, 1998.

2. Harada M, Sakisaka S, Terada K, et al. Role of $A T P 7 B$ in biliary copper excretion in a human hepatoma cell line and normal rat hepatocytes. Gastroenterology 118: 921-928, 2000.

3. Harada M. Wilson disease. Med Electron Microsc 35: 61-66, 2002.

4. Roberts EA, Schilsky ML. Diagnosis and treatment of Wilson disease: an update. Hepatology 47: 2089-2111, 2008.

5. Yanagimoto C, Harada M, Kumemura H, et al. Niemann-Pick C1 protein transports copper to the secretory compartment from late endosomes where $A T P 7 B$ resides. Exp Cell Res 315: 119-126, 2009.

6. Bull PC, Thomas GR, Rommens JM, Forbes JR, Cox DW. The Wilson disease gene is a putative copper transporting P-type ATPase similar to the Menkes gene. Nat Genet 5: 327-337, 1993.

7. Tanzi RE, Petrukhin K, Chernov I, et al. The Wilson disease gene is a copper transporting ATPase with homology to the Menkes disease gene. Nat Genet 5: 344-350, 1993.

8. Yamaguchi Y, Heiny ME, Gitlin JD. Isolation and characterization of a human liver cDNA as a candidate gene for Wilson disease. Biochem Biophys Res Commun 197: 271-277, 1993.

The Third Department of Internal Medicine, University of Occupational and Environmental Health, Japan School of Medicine, Kitakyushu Received for publication January 13, 2010; Accepted for publication January 21, 2010

Correspondence to Dr. Masaru Harada, msrharada@med.uoeh-u.ac.jp 
9. Walshe JM. Wilson's disease. New oral therapy. Lancet i: 25-26, 1956.

10. Yoshitoshi EY, Takada Y, Oike F, et al. Long-term outcomes for 32 cases of Wilson's disease after living-donor liver transplantation. Transplantation 87: 261-267, 2009.

11. Tatsumi Y, Hattori A, Hayashi H, et al. Current state of Wilson disease patients in central Japan. Intern Med 49: 809-815, 2010.

12. Walshe JM, Dixon AK. Dangers of non-compliance in Wilson's disease. Lancet 327: 845-847, 1986.

13. Scheinberg IH, Jaffe ME, Sternlieb I. The use of trientine in preventing the effects of interrupting penicillamine therapy in Wilson's disease. N Engl J Med 317: 209-213, 1987.

14. Prashanth LK, Taly AB, Sinha $S$, et al. Prognostic factors in pa- tients presenting with severe neurological forms of Wilson's disease. Q J Med 98: 557-563, 2005.

15. Ping CC, Hassan Y, Aziz NA, Ghazali R, Awaisu A. Discontinuation of penicillamine in the absence of alternative orphan drugs (trientine-zinc): a case of decompensated liver cirrhosis in Wilson's disease. J Clin Pharm Ther 32: 101-107, 1986.

16. Svetel M, Pekmezović T, Petrović I, et al. Long-term outcome in Serbian patients with Wilson disease. Eur J Neurol 16: 852-857, 2009.

17. Oder W, Grimm G, Kollegger H, Ferenci P, Schneider B, Deecke L. Neurological and neropsychiatric spectrum of Wilson's disease: a prospective study of 45 cases. J Neurol 238: 281-287, 1991.

(C) 2010 The Japanese Society of Internal Medicine http://www.naika.or.jp/imindex.html 